\title{
Experimental animal models for COPD: a methodological review
}

\author{
Vahideh Ghorani ${ }^{1}$, Mohammad Hossein Boskabady ${ }^{2 *}$, Mohammad Reza Khazdair ${ }^{1}$ and Majid Kianmeher ${ }^{2}$
}

\begin{abstract}
Introduction: Chronic obstructive pulmonary disease (COPD) is a progressive disorder that makes the breathing difficult and is characterized by pathological conditions ranging from chronic inflammation to tissue proteolysis. With regard to ethical issues related to the studies on patients with COPD, the use of animal models of COPD is inevitable. Animal models improve our knowledge about the basic mechanisms underlying COPD physiology, pathophysiology and treatment. Although these models are only able to mimic some of the features of the disease, they are valuable for further investigation of mechanisms involved in human COPD.

Methods: We searched the literature available in Google Scholar, PubMed and ScienceDirect databases for English articles published until November 2015. For this purpose, we used 5 keywords for COPD, 3 for animal models, 4 for exposure methods, 3 for pathophysiological changes and 3 for biomarkers. One hundred and fifty-one studies were considered eligible for inclusion in this review.

Results: According to the reviewed articles, animal models of COPD are mainly induced in mice, guinea pigs and rats. In most of the studies, this model was induced by exposure to cigarette smoke (CS), intra-tracheal lipopolysaccharide (LPS) and intranasal elastase. There were variations in time course and dose of inducers used in different studies. The main measured parameters were lung pathological data and lung inflammation (both inflammatory cells and inflammatory mediators) in most of the studies and tracheal responsiveness (TR) in only few studies.
\end{abstract}

Conclusion: The present review provides various methods used for induction of animal models of COPD, different animals used (mainly mice, guinea pigs and rats) and measured parameters. The information provided in this review is valuable for choosing appropriate animal, method of induction and selecting parameters to be measured in studies concerning COPD.

Keywords: Chronic obstructive pulmonary disease, Emphysema, Animal models, Methods, Inflammation, Lung pathology, Airway responsiveness, Cigarette smoke

\section{Background}

Chronic obstructive pulmonary disease (COPD) is a major cause of morbidity and mortality throughout the world and is characterized by chronic airway inflammation, mucus hypersecretion, airway remodeling, and emphysema, leading to reduced lung function and breathlessness [1-4]. Development of COPD is slow and progressive, with occasional exacerbations caused by inflammatory

\footnotetext{
* Correspondence: boskabadymh@mums.ac.ir; mhboskabady@hotmail.com ${ }^{2}$ Neurogenic Inflammation Research Centre and Department of Physiology, School of Medicine, Mashhad University of Medical Sciences, Mashhad 9177948564, Iran

Full list of author information is available at the end of the article
}

responses induced by triggering substances such as noxious gases, bacteria or viruses [2].

There are no effective treatments for COPD, because the mechanisms underlying COPD are poorly understood at the molecular level. The lack of a small-animal model that recapitulates the distinctive features of the disease in a certain time frame, is a major limiting factor in the study of COPD [1]. However, animal experimentation continues to provide approaches for treatment of all chronic diseases including those affecting the airways and lungs [5].

Animal models are used to study chronic obstructive pulmonary disease [6], investigate inflammatory processes 
[7] and determine the basic mechanisms of COPD [8]. Several animal species have been used as a model of COPD including rodents, dogs, guinea-pigs, monkeys and sheep [8] but an appropriate model highly depends on the aims of the study [9].

Different methods of induction of animal models of COPD, different animals used for this purpose and various measured parameters were comprehensively reviewed in the present article. Therefore, the present review will help investigators to choose an appropriate method for induction of an animal model of COPD and measure informative variables based on their study design.

\section{Methods}

\section{Search strategy}

A search for articles, published in English, from January 1967 to November 2015, was conducted using Google Scholar, PubMed and ScienceDirect databases. Overall, 221 relevant articles were identified from which, 70 articles excluded on the basis of the publication status, selected population and publication language. Therefore, 151 retrieved articles were eligible and were included in the review. The search terms included 5 keywords for COPD (chronic obstructive pulmonary disease, COPD, chronic bronchitis, emphysema, airway obstruction), 3 for animal model (animal model, animal experimentation, investigative techniques), 4 for exposure method (cigarette smoke (CS), lipopolysaccharide (LPS), elastase, combination inducers), 3 for pathophysiological changes (airway remodeling, airway inflammation, airway responsiveness) and 3 for biomarkers (biomarkers, cytokines, mediators).

\section{Inclusion and exclusion criteria}

Articles were included if they: 1) provided different animal models of COPD; 2) provided sufficient and clear detailed method of animal exposure to inducers of COPD; and 3) evaluated parameters indicating the induction of an animal model of COPD. Abstracts or unpublished articles, human studies and non-English language articles were excluded.

\section{Management of search results}

The search results were checked and included papers were reviewed by authors. We have presented information from each study and a qualitative conclusion was drawn.

\section{Inducers of COPD in various animal models}

There are different approaches to imitate COPD in animal models [10]. These approaches include exposing laboratory animals to CS (the primary etiological factor for COPD), inflammatory stimuli (e.g., LPS), proteolytic enzymes (e.g., elastase), and genetic modification [7, 11]. In this section, different inducers of COPD that have been used in various animals are reviewed (Table 1).

\section{Cigarette-smoke (CS)}

Tobacco smoking is the most important risk factor for COPD $[2,4]$ and the most common COPD-inducer employed in in vivo studies [12]. In addition, to mainstream cigarette smoke, environmental cigarette smoke may also contribute to respiratory symptoms and COPD [4]. Usually, standardized research-grade cigarettes should be used to easily deliver a specified dose of total suspended particles (TSP) or total particulate matter (TPM), including nicotine and carbon monoxide. These cigarettes are most commonly used in the University of Kentucky [13]. However, currently, there is no standardized method or protocol for animal exposure and this is one of the limitations of the use of CS as an in vivo COPD-inducer. Therefore, the type of cigarettes used to generate smoke (commercial vs. research cigarettes, with or with-out a filter), the constituents of the CS used for exposures, delivery systems (whole body vs. nose-only), and most significantly, the dose of smoke delivered to the animals are important determinant factors [7, 14]. Despite these limitations, CS has been shown to induce many features of COPD in animals, including pulmonary infiltration of macrophages and neutrophils, airway fibrosis and emphysema [9, 15-21]. A variety of animal species exposed to tobacco smoke to mimic COPD is described in this section $[10,13]$.

\section{Mice}

These have been the most commonly used species exposed to CS for induction of animal model of COPD $[7,22]$. Concerning the immune mechanisms, mice are the best choice as animal models of COPD. Furthermore, the murine genome has been greatly sequenced, and has shown similarities to human genomes [23]; Also, the possibility to manipulate gene expression are suggested [10, 13, 24, 25]. However, several studies have shown that different strains of mice show various levels of sensitivity to CS challenge [7]. Different exposure protocols were used in several studies and mice were exposed to CS once or twice/day, several times/week for various days/weeks/months in a smoking apparatus as whole body exposure [26-31] or nose-only exposure [32-34], (Table 1).

\section{Rats}

Rats are also used as animal models of COPD [10, 24], but they are known as a poor model [16, 35], because these animals seem to be relatively resistant to development of COPD [10, 16, 24]. However, several studies have used rats because measurable emphysematous changes 
Table 1 Different method used for induction of animal model of COPD and various measured parameters in each model

\begin{tabular}{|c|c|c|c|c|c|c|}
\hline \multirow[t]{2}{*}{ Induce. } & \multirow[t]{2}{*}{ Animal } & \multirow[t]{2}{*}{ Method } & \multicolumn{3}{|c|}{ Measured parameters } & \multirow[t]{2}{*}{ Ref. } \\
\hline & & & $\overline{T R}$ & Path & $\operatorname{lnfl}$ & \\
\hline \multirow[t]{25}{*}{ Cigarette } & \multirow[t]{15}{*}{ Mice } & $-2 \times 75 \mathrm{~min} /$ day, 5 day/week, for $1-12$ weeks & & $\checkmark$ & & {$[1]$} \\
\hline & & $-2 \times 30 \mathrm{~min} /$ day, 3 consecutive days, whole body exposure & & & & [26] \\
\hline & & $\begin{array}{l}-12 \mathrm{Cig} \times 2 \times 50 \mathrm{~min} / \text { day, } 5 \text { day/week, for } 8-24 \text { weeks, whole } \\
\text { body exposure }\end{array}$ & & $\checkmark$ & C & [30] \\
\hline & & $\begin{array}{l}-150 \pm 15 \mathrm{mg} / \mathrm{m}^{3} \mathrm{CS} \text { of TSP, } 4 \mathrm{~h} / \text { day, } 5 \text { day/week, whole } \\
\text { body exposure }\end{array}$ & & & & {$[27,28]$} \\
\hline & & $-150 \mathrm{mg} / \mathrm{m}^{3} \mathrm{CS}$ of TPM, $3 \mathrm{~h} /$ day, 5 day/week, for 6 months & & & & [136] \\
\hline & & $\begin{array}{l}-5 \text { Cig ( } 12 \mathrm{mg} \text { of tar, } 0.9 \mathrm{mg} \text { of nicotine, without } \\
\text { filter) } \times 4 / \text { day, } 30 \mathrm{~min} \text { rest, } 5 \text { day/week, for } 24 \text { weeks }\end{array}$ & & $\checkmark$ & & [118] \\
\hline & & $\begin{array}{l}-250 \text { and } 500 \mathrm{mg} / \mathrm{m}^{3} \mathrm{CS} \text { of TPM, } 2 \times 50 \mathrm{~min} / \text { day, } \\
3 \text { consecutive days, nose only and whole body exposure }\end{array}$ & & & $M$ & [22] \\
\hline & & - 5/day, 5 day/week, for 6 months & & & & [142] \\
\hline & & - 5 h/day, 5 days/week, for 6 months, whole body exposure & & $\checkmark$ & C & [29] \\
\hline & & $\begin{array}{l}-150 \pm 15 \mathrm{mg} / \mathrm{m}^{3} \mathrm{CS} \text { of TSP, } 4 \mathrm{~h} / \text { day, } 5 \text { day/week, } \\
\text { for } 6 \text { months }\end{array}$ & & & & [143] \\
\hline & & $\begin{array}{l}-12 \text { Cig } \times 2 \times 75 \mathrm{~min} / \text { day, } 5 \text { day/week, for } 1-12 \text { weeks, } \\
\text { nose only exposure }\end{array}$ & & $\checkmark$ & $\mathrm{C} / \mathrm{M}$ & [32] \\
\hline & & $\begin{array}{l}\text { - } 3 \text { Cig (with filter), } 5 \text { day/week, for } 6 \text { months, nose } \\
\text { only exposure }\end{array}$ & & $\checkmark$ & C & [33] \\
\hline & & $\begin{array}{l}\text { - } 10 \text { Cig (without filter), } 512.6 \mathrm{mg} / \mathrm{m}^{3} \text { CS of TPM, } 2 \times 35 \mathrm{ml} \\
\text { puffs } / \mathrm{min}, 50 \mathrm{~min} / \text { day, } 5 \text { day/week, for 22, 24, } 45 \text { days, } \\
\text { nose only exposure }\end{array}$ & & & C & [34] \\
\hline & & $\begin{array}{l}\text { - } 3 \text { Cig ( } 12 \mathrm{mg} \text { of tar, } 0.9 \mathrm{mg} \text { of nicotine)/day, } 5 \text { day/week, } \\
\text { for } 4 \text { or } 7 \text { months }\end{array}$ & In vivo & & & [120] \\
\hline & & $\begin{array}{l}-103.36 \pm 1.09 \mathrm{mg} / \mathrm{m}^{3} \mathrm{CS} \text { of TPM, } 2 \times 70-\mathrm{cm}^{3} \mathrm{puffs} / \mathrm{min} \\
6 \mathrm{~h} / \text { day, } 7 \text { day/week, whole body exposure }\end{array}$ & & & & [31] \\
\hline & \multirow[t]{7}{*}{ Rat } & $\begin{array}{l}-8 \mathrm{Cig}(14 \mathrm{mg} \text { of tar, } 1.2 \mathrm{mg} \text { of nicotine, } 15 \mathrm{mg} \text { of } \\
\mathrm{CO}) \times 2 \times 30 \mathrm{~min} / \text { day, } 3-4 \mathrm{~h} \text { interval between them, } \\
\text { for first } 2 \text { weeks and } 15 \mathrm{Cig}(14 \mathrm{mg} \text { of tar, } 1.2 \mathrm{mg} \text { of } \\
\text { nicotine, } 15 \mathrm{mg} \text { of } \mathrm{CO}) \times 3 \times 30 \mathrm{~min} / \text { day, } 3-4 \mathrm{~h} \text { interval } \\
\text { between them, from the third to the twelfth week }\end{array}$ & & $\checkmark$ & M & {$[2]$} \\
\hline & & $\begin{array}{l}-12 \mathrm{Cig}(10 \mathrm{mg} \text { of tar, } 0.8 \mathrm{mg} \text { of nicotine, } 10 \mathrm{mg} \text { of } \mathrm{CO} \text {, } \\
\text { with filter) } \times 3\end{array}$ & & $\checkmark$ & & {$[37]$} \\
\hline & & -20 Cig $\times 2 /$ day, $4-5 \mathrm{~h}$ interval between them, for 4 months & & $\checkmark$ & C & [38] \\
\hline & & $\begin{array}{l}-80-90 \mathrm{mg} / \mathrm{m}^{3} \mathrm{CS} \text { of TSP, } 1 \times 35 \mathrm{ml} \text { puffs ( } 2 \text {-s duration)/min, } \\
6 \mathrm{~h} / \text { day, } 3 \text { day/week, for } 3 \text { days or } 4 \text { weeks or } 12 \text { weeks, } \\
\text { whole body exposure }\end{array}$ & & $\checkmark$ & & [39] \\
\hline & & - 10 min/day, for 7 weeks & & & & {$[40]$} \\
\hline & & $\begin{array}{l}-1 \times 35 \mathrm{ml} \text { puffs (2-s duration)/min, } 6 \mathrm{~h} / \text { day, } 3 \text { day, whole } \\
\text { body exposure }\end{array}$ & & & C & [41] \\
\hline & & $\begin{array}{l}\text {-Cig ( } 25 \mathrm{mg} \text { tar, } 1.4 \mathrm{mg} \text { nicotine }) \times 2 \times 1 \mathrm{~h} / \text { day, } 7 \text { day/week, } \\
\text { for } 2,4,6,8,10,12,24,36 \text { weeks }\end{array}$ & & $\checkmark$ & C & [42] \\
\hline & \multirow[t]{3}{*}{ Guinea pig } & $\begin{array}{l}-1-5 \mathrm{Cig}(5 \mathrm{mg} \text { nicotine, } 6 \mathrm{mg} \text { tar, with filter), } 2 \times 20 \mathrm{ml} \\
\text { puffs/Cig/min, } 8-9 \mathrm{~min} / \mathrm{Cig} / \mathrm{day}, 10 \mathrm{~min} \text { interval between } \\
\text { cigarettes, } 5 \text { or } 6 \text { day/week, for } 3 \text { consecutive months, } \\
\text { nose only exposure }\end{array}$ & In vitro & $\checkmark$ & $\mathrm{C} / \mathrm{M}$ & {$[50-53]$} \\
\hline & & $\begin{array}{l}-1-5 \mathrm{Cig} \text { ( } 5 \mathrm{mg} \text { nicotine, } 6 \mathrm{mg} \text { tar, without filter), } \\
2 \times 20 \mathrm{ml} \mathrm{puffs/Cig/min,} 8-9 \mathrm{~min} / \mathrm{Cig} / \mathrm{day}, 10 \mathrm{~min} \\
\text { interval between cigarettes, } 5 \text { or } 6 \text { day/week, for } 3 \\
\text { consecutive months, nose only exposure }\end{array}$ & In vitro & $\checkmark$ & & {$[54-58]$} \\
\hline & & $\begin{array}{l}-4 \text { Cig }(5.3 \pm 0.1 \mathrm{mg} / \mathrm{l} \text { concentration of CS), } 30 \\
\mathrm{min} / \mathrm{day}, 7 \mathrm{day} / \text { week }\end{array}$ & & & & [144] \\
\hline
\end{tabular}


Table 1 Different method used for induction of animal model of COPD and various measured parameters in each model (Continued)

\begin{tabular}{|c|c|c|c|c|c|}
\hline & & $\begin{array}{l}-10 \text { Cig, } 2 \times 20 \mathrm{ml} \text { puffs } / \mathrm{min}, 8-9 \mathrm{~min} / \mathrm{Cig} / \text { day, } 10 \\
\text { min rest, for } 1-60 \text { days }\end{array}$ & & & {$[13,145]$} \\
\hline & & - 10 Cig (without filter)/day,5 day/week, for1-12 months & & & [44] \\
\hline & & - 7 Cig (without filter)/day, 5 day/week, for 3-6 months & & & {$[13,146]$} \\
\hline & & -5 Cig/day, 5 day/week, for 6 months & & & {$[13,147,148$} \\
\hline & & - 2 h/day, 5 day/week, for 24 weeks & & & {$[13,149]$} \\
\hline & Dog & $\begin{array}{l}-2-7 \text { Cig }(0.27 \mathrm{mg} \text { tar, } 3.25 \mathrm{mg} \text { nicotine, without filter)/day, } \\
2 \times 35 \mathrm{ml} \mathrm{puffs/Cig} / 20 \mathrm{~s}, 7 \text { day/week, for } 2-4 \text { months }\end{array}$ & & & [62] \\
\hline & & -12 Cig/day, 7 day/week, for 5 months & & & [150] \\
\hline & & $\begin{array}{l}-10 \mathrm{Cig} \text { (20 mg tar, } 1.2 \mathrm{mg} \text { nicotine, without filter)/day, } \\
2.5 \mathrm{~h} / \text { day, } 5 \text { day/week, for } 6 \text { or } 10 \text { months }\end{array}$ & & & {$[59,151]$} \\
\hline & Monkey & - 6 h/day, 5 day/week, for 7 months & $\checkmark$ & C & {$[64,65]$} \\
\hline LPS & Mice & $\begin{array}{l}\text {-IN } 0.3 \mathrm{mg} / \mathrm{kg} \text { of LPS, animals were killed } 24 \mathrm{~h} \text { after the } \\
\text { challenge to LPS }\end{array}$ & & & [26] \\
\hline & & - IN $7 \mu \mathrm{g}$ of LPS, 1 day/week, for 4 consecutive weeks & $\checkmark$ & C & [77] \\
\hline & & $\begin{array}{l}\text { - intrapulmonary instillation, } 0.5 \mathrm{mg} / \mathrm{kg} \text {; volume } \\
=100 \mathrm{\mu L} \text { of LPS }\end{array}$ & & M & {$[79,80]$} \\
\hline & Guinea pig & $\begin{array}{l}\text {-IN } 200 \mathrm{~mL} \text { of LPS (5 mg/mL in sterile saline), twice/week, } \\
\text { for } 12 \text { consecutive weeks }\end{array}$ & $\checkmark$ & & [69] \\
\hline & & $\begin{array}{l}\text {-IN } 100 \mu \mathrm{L} \text { of LPS ( } 10 \mathrm{mg} / \mathrm{ml} \text { in sterile saline), twice/week, } \\
\text { for } 12 \text { consecutive weeks }\end{array}$ & $\checkmark$ & C & {$[77,82]$} \\
\hline & Rat & - aerosolized LPS, 30 min/day & $\checkmark$ & $\mathrm{C} / \mathrm{M}$ & [81] \\
\hline Elastase & Mice & - IN 1.2 U of PPE, 1 day/week, for 4 consecutive weeks & $\checkmark$ & C & [77] \\
\hline & & - IT $2 \mathrm{U}$ of PPE/100 g body wt in $100 \mu \mathrm{l}$ saline & & & [95] \\
\hline & Rat & - IT $28 \mathrm{U}$ of PPE/100 g body wt & & & [96] \\
\hline & & - IT $55 \mathrm{U}$ of PPE/100 g body wt in $0.5 \mathrm{ml}$ saline & $\checkmark$ & & [97] \\
\hline & & $\begin{array}{l}\text { - IT } 0.55 \mathrm{U} \text { of PPE } / 100 \mathrm{~g} \text { body wt in } 0.7 \mathrm{ml} \text { or } 0.3 \mathrm{ml} \\
\text { of } 0.15 \mathrm{M} \mathrm{NaCl}\end{array}$ & & M & [98] \\
\hline & Hamster & - IT $55 \mathrm{U}$ of PPE/100 g body wt in $0.3 \mathrm{ml}$ saline & & & [97] \\
\hline & & $\begin{array}{l}\text { - IT } 0.55 \mathrm{U} \text { of PPE/100 g body wt in } 0.7 \mathrm{ml} \text { or } 0.3 \mathrm{ml} \\
\text { of } 0.15 \mathrm{M} \mathrm{NaCl}\end{array}$ & & M & [98] \\
\hline Combination Inducers & Mice & $\begin{array}{l}\text { - IN } 1.2 \mathrm{U} \text { of PPE, on day } 1 \text { and IN } 7 \mu \mathrm{g} \text { of LPS on day } 4 \text {, } \\
\text { for } 4 \text { consecutive weeks }\end{array}$ & $\checkmark$ & C & [77] \\
\hline & Rat & $\begin{array}{l}-2 \times 30 \mathrm{~min} / \text { day exposure to CS, for } 2 \text { days and on } 3 \text { day } \\
\text { exposure to aerosolized LPS for } 30 \mathrm{~min} ; 5 \mathrm{~h} \text { after LPS } \\
\text { exposure, exposure to CS for } 30 \mathrm{~min}\end{array}$ & & $\mathrm{C} / \mathrm{M}$ & [81] \\
\hline
\end{tabular}

IT intra tracheal, IN intranasal, Ref. references, Cig cigarette, $h$ hours, Sec second, CS cigarette smoke, CO carbon monoxide, wt weight, LPS lipopolysaccharide, PPE porcine pancreatic elastase, TSP total suspended particles, TPM total particulate matter, TR tracheal responsiveness, Path lung pathology, Infl inflammation, $C$ cell, $M$ mediators

can be distinguished only 2 months after CS-exposure [13, 36]. Several studies showed that emphysema development in mice significantly differ from that in rats [24]. Different methods of induction of COPD in rats, based on exposure method and duration, and cigarette type [2, 37-42] are shown in Table 1.

\section{Guinea pigs}

Guinea pigs are suitable species that are commonly used in COPD studies [12, 43-46]. These animals have many advantages as there are similarities between the anatomy and physiology of their lungs with those of humans [46-49]. In addition, various similarities in physiological processes, especially airway autonomic control and response to allergen, have been shown between guinea pigs and humans $[16,44,46]$. However, there are disadvantages such as lack of molecular tools, the need to test numerous compounds for pharmacological studies, and the cost of purchasing and keeping the animals [10]. Since, the advantages outweigh the disadvantages, guinea pigs are being applied in studies related to asthma and COPD $[13,46]$. These studies 
indicated that guinea pigs develop COPD and emphysemalike lesions after a few months of exposure to active tobacco smoke [44] and physiological changes that mimic COPD in humans were showed in smoke-exposed guinea pigs $[16,44]$. For example, in order to induce COPD in these animals, guinea pigs were exposed for 8-9 min to 5 cigarettes/day, 5 or 6 days per week for 3 consecutive months, with [50-53] or without filter [54-58], (Table 1).

\section{Canine (Dog)}

Dogs have been extensively used as a model of asthma and COPD [59], because the pathology and pathophysiology of chronic bronchitis and emphysema after exposure to CS in dogs are similar to humans [59-61]. The canine model, similar to other models of COPD, has been used to examine new treatments before testing them in humans [59]. In a study, pulmonary fibrosis and emphysema were produced in dogs after direct inhalation of CS in a short period of time [62], (Table 1).

\section{Monkey}

Another appropriate animal model for investigation of mechanisms underlying allergic airways diseases and COPD, is non-human primates. It was shown that monkeys exposed to CS, exhibit chronic respiratory bronchiolitis and other airway alterations [63]. Exposure to $C S$ for $6 \mathrm{~h} /$ day, 5 days/week with a total suspended particulate concentration of $1 \mathrm{mg} / \mathrm{m}^{3}$, can generate experimental COPD in monkeys [64, 65], (Table 1).

\section{Lipopolysaccharide (LPS)}

LPS instillation was shown to be able to induce a shortterm model of COPD with some human features of the disease [6, 66]. LPS (a major component of the outer cell wall of Gram-negative bacteria) is present as a contaminant in CS, air pollution and organic dusts [9, 67-69]. LPS induces acute COPD exacerbations, when given either alone or concomitant with CS [16]. In addition, LPS may be important in bacterial infection-induced exacerbations of COPD, which contribute to the development of the disease [69, 70]. Chorionic exposure of animals to LPS has been shown to induce pathological features of COPD, such as pulmonary inflammation and airway hyperresponsiveness (AHR) as well as structural changes in the lung $[9,69,71-76]$. Inflammatory responses are induced after 12 weeks of twice-weekly LPS exposure $[9,76]$. Several studies that used LPS for induction of COPD in animals are listed in Table 1.

\section{Mice}

Investigations indicated that exposure of mice to inhaled LPS leads to emphysema-like changes which persisted for up to 4 weeks [74, 77]. In addition, it was reported that LPS is able to induce pathological and physiological changes of COPD such as AHR and increased airway inflammation in mice $[77,78]$. In these studies, LPS was administered through intrapulmonary instillation using a MicroSprayer aerosolizer $[79,80]$ or via intranasal route $[26,77]$ (Table 1).

\section{Rats}

In rat models, LPS can be inhaled in the same manner as mice resulting in pathological features of COPD [81], (Table 1).

\section{Introduction}

Studies have demonstrated that LPS can induce COPD pathological features, similar to those of COPD patients, in guinea pigs. In these studies, guinea pigs were given intranasal instillation of LPS twice weekly, for 12 consecutive weeks $[69,77,82]$, (Table 1).

\section{Elastase}

Elastase is a proteolytic enzyme, which is released by activated neutrophils in the lungs and leads to breakdown of alveolar tissue and emphysema $[9,83]$. The elastase model consists of instillation of elastolytic enzymes (such as the porcine pancreatic elastase (PPE), human neutrophilic elastase and papain) in the lung resulting in tissue damage and development of emphysema $[9,10,84-86]$. This model is used to induce inflammatory responses to initiate and perpetuate the inflammatory response seen in COPD [12, 87, 88]. The major advantages of the elastase model are the technical ease of inducing the disease by a single instillation of the enzyme in the lung and the ability to control the disease severity by adjusting the amount of enzyme $[9,16,89,90]$. However, the disadvantage of the elastase model is that the function of elastase in COPD emphysema depends on several pathophysiological mechanisms which again brings up the number of clinical events [12, 91, 92]. A wide variety of animals has been used in the elastase emphysema model $[16,83,93]$ to reproduce some characteristics of human CS-induced disease, such as augmentation of airspaces, inflammatory cell influx into the lungs, and systemic inflammation [84]. In some studies, to reproduce human pulmonary emphysema, intratracheal instillation of elastase was used in mouse models for more than three decades so, they are well characterized [94, 95]. Other studies used rats and hamsters to reproduce elastase-induced emphysema [96-98].

\section{Mice}

A mouse model of COPD using elastase instillation could be produced by intranasal exposure to 1.2 units (U) of porcine pancreatic elastase 1 day/week for 4 
consecutive weeks [77]. In some studies, mice received 2 $\mathrm{U} / 100 \mathrm{~g} / \mathrm{BW}$ porcine pancreatic elastase dissolved in 100 $\mu \mathrm{l}$ phosphate-buffered saline solution, intra-tracheally [95], (Table 1).

\section{Rats}

Rats emphysema model was developed by injection of a single dose of intra-tracheal elastase (28 U/100 g/BW) and studied 7, 15, 30 and 365 days after injection [96]. In other studies, rats received a single intra-tracheal dose of elastase $(55 \mathrm{U} / 100 \mathrm{~g} / \mathrm{BW}$ dissolved in $0.5 \mathrm{ml}$ physiological saline or $0.55 \mathrm{U} / 100 \mathrm{~g} / \mathrm{BW}$ diluted in 0.7 $\mathrm{ml}$ or $0.3 \mathrm{ml}$ of $0.15 \mathrm{M} \mathrm{NaCl}$ ), [97]. In a study, Borzone et al. showed that 4 months after intra-tracheal instillation of a similar single dose of elastase, severe pulmonary emphysema with profound alterations in respiratory mechanics, were observed in hamsters [97, 98], (Table 1).

\section{Combination inducers}

Animal models that mimic different aspects of inflammatory responses in COPD, could be developed by concomitant use of different inducers such as CS, LPS and PPE. For example, mice could be intranasally challenged with PPE and LPS for 4 weeks to induce COPDlike lung inflammation [77]. In another study, increased inflammatory response was observed following rats exposure to a combination of LPS and CS. In this model, rats were exposed to CS for $30 \mathrm{~min}$ twice a day for 2 days. On day 3 animals were exposed to LPS for $30 \mathrm{~min}$ and $5 \mathrm{~h}$ later, they were exposed to CS [81], (Table 1).

\section{Other models}

Other agents have also been used to induce airway inflammation injury. The apoptosis model focuses on the failure of COPD lung to repair itself post-injury focusing on dis-regulated normal lung tissue turnover. Apoptosisinduced COPD has been linked to inhibition of VEGF receptors [12, 16, 99-101]. This model induces enlarged airspaces in a short period of time but does not affect the airways [12, 16]. In addition, genetically-altered models that mimic COPD, have been developed in recent years [10, 102, 103]. These models could be used for recognition of both physiological functions of different genes as well as possible mechanisms of COPD [10]. For example, emphysema and airspace enlargement can occur following exposure to CS, in gene-targeted mice [104]. However, currently, this model has been mostly restricted to proteinase "knockouts" in gene-targeted mice. These studies have uncovered an important role for macrophage elastases, particularly matrix metalloproteinase- 12 (MMP-12) [105, 106], and a crucial role for neutrophil elastase $[106,107]$. In this method, overexpression of interleukin 13 (IL-13), [108] and interferon gamma (IFNY) was demonstrated [109], both leading to inflammation and airspace enlargement. IFN $\gamma$ is also a marked element of structural cell apoptosis [106].

\section{Measured parameters Pathological changes}

A main characteristic of COPD is airflow obstruction which is mostly irreversible. The airway obstruction may be the result of a combination of small airways narrowing, airway wall inflammation $[10,110]$ and emphysemarelated loss of lung elastic recoil $[1,10,111,112]$. Structural changes of the lung such as emphysema and small airway remodeling, are the pathologic features of COPD [113]. Small airway remodeling in COPD occurs via sub-epithelial fibrosis, mucus cell hyperplasia and in some cases, increase airway smooth muscle (ASM) mass [9, 113-117]. In addition, persistent infiltration of inflammatory cells such as macrophages, neutrophils, $\mathrm{T}$ and B-lymphocytes in the airway wall are features of airway remodeling [115-117] which could be caused directly by CS and LPS exposure of structural cells of the airway wall, independent of inflammation [9].

\section{Mice}

Chronic inflammation, increased cellular infiltration in the lung parenchyma, increased numbers of mucus-secreting goblet cells, thickening of airway epithelium and alveolar enlargement as well as airway remodeling in mouse models of CS-induced COPD were observed [1]. Also, in a mouse model of PPE and LPS-induced COPD, airway remodeling, lung inflammation, goblet cell hyperplasia, and alveolar enlargement were observed [77]. Similarly, emphysematous destruction, parenchymal inflammation, mucus hyper secretion and airway remodeling in a mouse model of COPD, were reported after CS exposure [29, 30, $32,64,118,119]$. In addition, significant increases in airway wall thickness and airspace size were observed after smoke exposure in mice $[33,120]$.

\section{Rats}

Increased bronchiole and arteriole wall thickness, bronchiole stenosis, increased alveolar size were shown in a rat model of COPD [2]. Lung function parameters such as airway resistance, respiratory system resistance, tissue damping, tissue elastance and respiratory system compliance increased in CS-treated rats [37]. In addition, elastase-treated rats showed mild airspace enlargement, fragmentation of alveolar spaces and inflammation [97, 121]. Elevation of neutrophils counts, mucus secretion, edema and lung inflammation in the lung and/or bronchoalveolar lavage were also seen in rat models of COPD [81]. In addition, an increase in airway wall thickness and airway narrowing, peribronchiolar inflammation, infiltration of large amount of inflammatory cells around the airways, enlargement of alveolar airspaces, destruction 
of septal walls of alveoli and pulmonary bullae as a morphological change seen in emphysema, were reported in a rat model of CS-induced COPD [38]. Damage of bronchial airway epithelium, neutrophil infiltration in the bronchial wall and epithelium were observed in rats following exposure to smoke [39]. Similarly, hyperplasia of bronchial epithelial cells, hypersecretion of mucus and development of peribronchial fibrosis were also found in rat models of COPD [42].

\section{Guinea pigs}

Baarsma et al. showed pulmonary inflammation and tissue remodeling, inflammatory cell influx, and enhanced small airway collagen content in LPS-induced guinea pig models of COPD [82]. Increased interalveolar septum, presence of lymphatic tissue in the lung parenchyma, destruction of alveolar wall, and existence of emphysema in the lung and intra-alveolar bleeding of lungs were also observed in guinea pig models of COPD following exposure to CS [50, 51, 54-57]. In another study, airway and parenchymal neutrophilia, increased goblet cell numbers, lung hydroxyproline content, airway wall collagen and airspace size, were reported [69]. Lung pathological changes in different animal models of COPD were summarized in Table 2.

\section{Tracheal responsiveness (TR)}

Airway hyperresponsivness (AHR) is the main characteristic of asthma which also exists in COPD [54]. Moreover, tracheal responsiveness (TR) to different stimuli is observed not only in asthmatic animals but

Table 2 Lung pathology and tracheal responsiveness evaluation in animal model of COPD

\begin{tabular}{|c|c|c|c|c|}
\hline \multirow{2}{*}{\multicolumn{2}{|c|}{$\frac{\text { Parameters }}{\text { Lung Pathology }}$}} & \multirow{4}{*}{$\begin{array}{l}\text { Animals } \\
\text { Mice }\end{array}$} & \multirow{2}{*}{$\begin{array}{l}\text { Methods } \\
\text {-Chronic lung inflammation, infiltration of cells in the parenchyma, mucosal } \\
\text { secretion, ticking of airway epithelium, alveolar enlargement, airway remodeling, } \\
\text { goblet cell hyperplasia }\end{array}$} & \multirow{2}{*}{$\frac{\operatorname{Ref}}{[1,77]}$} \\
\hline & & & & \\
\hline & & & $\begin{array}{l}\text { - Emphysematous destruction, parenchymal inflammation, mucus hyper secretion, } \\
\text { airway remodeling }\end{array}$ & {$[29,30,32,64,118,119]$} \\
\hline & & & - Increased wall thickness and airspace size & {$[33,120]$} \\
\hline & & \multirow[t]{7}{*}{ Rat } & $\begin{array}{l}\text { - Increasing of bronchiole and arteriole wall thickness, bronchiole stenosis, } \\
\text { increased alveolar size }\end{array}$ & [2] \\
\hline & & & $\begin{array}{l}\text { - Airway resistance, respiratory system resistance, tissue damping, tissue elastance, } \\
\text { increased respiratory system compliance }\end{array}$ & [37] \\
\hline & & & - Airspace enlargement, fragmentation of alveolar spaces, inflammation & {$[97,121]$} \\
\hline & & & $\begin{array}{l}\text { - Elevation of neutrophils, mucus, oedema, lung inflammation in lung and/or } \\
\text { bronchoalveolar lavage }\end{array}$ & {$[81]$} \\
\hline & & & $\begin{array}{l}\text { - Increased wall thickness, airway narrowing, peribronchiolar inflammation, } \\
\text { inflammatory cell infiltration, enlargement of alveolar airspaces, destruction } \\
\text { of septal walls of alveoli and pulmonary bullae }\end{array}$ & [38] \\
\hline & & & - Bronchial airway epithelium injury, neutrophil infiltration & {$[39]$} \\
\hline & & & $\begin{array}{l}\text { - Hyperplasia of bronchial epithelial cells, hypersecretion of mucus, } \\
\text { peribronchial fibrosis }\end{array}$ & [42] \\
\hline & & \multirow[t]{3}{*}{ Guinea pig } & - Pulmonary inflammation and tissue remodeling & [82] \\
\hline & & & $\begin{array}{l}\text { - Increased interalveolar septum, increased lymphatic tissue in lung parenchyma, } \\
\text { destruction of alveolar wall, emphysema in the lung, intra-alveolar bleeding }\end{array}$ & {$[50,51,54-57]$} \\
\hline & & & $\begin{array}{l}\text { - Airway and parenchymal neutrophilia, increased goblet cell numbers, } \\
\text { elevation of lung hydroxyproline content, increasing of airway wall collagen } \\
\text { and airspace size }\end{array}$ & [69] \\
\hline \multirow[t]{6}{*}{ TR } & In vivo & Mice & $\begin{array}{l}\text { - Inhaled Mch: }(6,12,25 \text {, and } 50 \mathrm{mg} / \mathrm{ml}, 1 \text { min, measuring Penh by WBPle } \\
\text { after } 10 \mathrm{~min}\end{array}$ & [31] \\
\hline & \multirow[t]{5}{*}{ In vitro } & \multirow[t]{5}{*}{ Guinea pig } & - TC preparation; Mch ( $10^{-7}$ to $\left.10^{-5} \mathrm{mM}\right)$ every 2 min, measuring $\mathrm{EC}_{50}$ using $\mathrm{CRC}$ & [52] \\
\hline & & & - TC preparation; Mch (10 nM to $5 \mathrm{mM}$ ) every 2 min, measuring $\mathrm{EC}_{50}$ using CRC & [56] \\
\hline & & & - TC preparation; Mch ( $10^{-7}$ to $10^{-2} \mathrm{mM}$ ) every 3 min, measuring $\mathrm{EC}_{50}$ using $\mathrm{CRC}$ & [58] \\
\hline & & & - TC preparation; histamine $(0.1 \mu \mathrm{M}-10 \mathrm{mM})$ every 2 min, measuring $\mathrm{EC}_{50}$ using $\mathrm{CRC}$ & {$[54,57]$} \\
\hline & & & $\begin{array}{l}\text { - TC preparation; isoprenaline }(10 \mathrm{nmol} / \mathrm{L} \text { to } 100 \mu \mathrm{mol} / \mathrm{L}) \text { every } 2 \mathrm{~min} \text {, measuring } \\
\mathrm{EC}_{50} \text { using } \mathrm{CRC}\end{array}$ & {$[55]$} \\
\hline
\end{tabular}


also in animals exposed to CS [122-126]. This parameter was assessed in some of COPD animal models, in vivo or in vitro.

\section{In vivo measurement of TR}

In vivo evaluation of TR has been usually examined by measurement of enhanced pause (Penh) using wholebody plethysmograph after inhalation of increasing doses of methacholine (Mch) aerosol [31].

\section{Mice}

AHR was assessed by methacholine challenge and measurement of Penh using whole body plethysmography in CS-exposed mice. The main indicator of airway obstruction, measured as Penh, shows a strong correlation with airway resistance measured using standard procedures $[31,127]$ and was calculated from the chamber-pressure-time curve.

\section{In vitro measurement of TR}

In several in vitro studies, tracheal responsiveness to Mch, histamine and isoprenaline was examined using cumulative concentrations-response curve of the corresponding agent and determination of $\mathrm{EC}_{50}[52,54$, $55,57,128,129]$.

\section{Guinea pigs}

In a study, the tracheal muscle responses of a guinea pig model of COPD (induced by CS) to cumulative concentrations of histamine $(0.1 \mu \mathrm{M}$ to $10 \mathrm{mM})$ were measured. Then, cumulative concentrations- response curve was plotted and the effective concentrations of histamine causing $50 \%$ of maximum response $\left(E_{50} \mathrm{H}\right)$ were calculated [54, 57]. In addition, concentration-response curves for isoprenaline in guinea pigs exposed to CS were also constructed by repeated administration of isoprenaline and $\mathrm{EC}_{50}$ was determined [55]. Similarly, tracheal responsiveness to Mch was also measured in tracheal smooth muscle by assessing the contraction induced by each concentration of Mch in proportion to the maximum contraction obtained by the final concentration of Mch in an animal model of CS-induced COPD $[52,56,58]$. Different methods of TR measurements in various animal models of COPD were summarized in Table 2.

\section{Inflammatory cells and mediators}

\section{Total and differential white blood cell (WBC) counts}

A variety of cell types is involved in the pathophysiology of COPD including neutrophils, macrophages, CD8-Tlymphocytes and eosinophils (which may play a major role in acute exacerbations of COPD). They release several inflammatory mediators and tissue-degrading enzymes which can orchestrate tissue destruction and chronic inflammation [10, 104, 130-135].

\section{Mice}

An increase in total cell number, mononuclear cells such as macrophages and lymphocytes (particularly CD8+ T cells) as well as neutrophils was shown in bronchoalveolar lavage (BAL) samples of mouse models of COPD $[29,30,32,34,77,136,137]$. Increased total inflammatory cell counts were reported in BAL of animal models of COPD which were mostly due to an increase in macrophages and neutrophils counts [33, 64].

\section{Rats}

Total inflammatory cells and neutrophils were increased in BAL of rat models of COPD [81]. Increased total leukocytes, macrophages, neutrophils and lymphocytes in BAL of rats after exposure to tobacco smoke were also reported $[39,41,42]$.

\section{Guinea pigs}

Total WBC [51] and eosinophil counts in blood were increased in guinea pig models of CS-induced COPD [50, 53]. Total WBC, eosinophils and neutrophils in lung lavage of COPD guinea pigs were also increased [52]. In Table 3, a summary of total and differential WBC in the blood and lung lavage in different animal models of COPD was presented.

\section{Inflammatory mediators and cytokines}

Several inflammatory mediators are involved in COPD pathogenesis [10, 138]. For example, macrophages secrete inflammatory mediators such as interleukin 8 (IL$8)$, tumor necrosis factor alpha (TNF- $\alpha$ ), leukotriene B4 (LTB4) [135, 139], reactive oxygen species (ROS), monocyte chemotactic protein 1 (MCP-1) and elastolytic enzymes such as matrix metalloproteinase (MMP-2, MMP-9, MMP-12), and cathepsins $\mathrm{K}, \mathrm{L}$, and $\mathrm{S}$ in response to CS and other stimuli [140]. Also, neutrophils evidently contribute to COPD pathogenesis by secretion of serine proteases (neutrophil elastase, cathepsin G, proteinase) and metalloelastases MMP-8 and MMP$9[135,140]$. In addition, IL-13, a Th2 cytokine has been proposed to be implicated in the pathophysiology of COPD [10, 141].

\section{Mice}

Duan et al. reported that the levels of IL-8, TNF- $\alpha$, and IFN- $\gamma$ in BAL of smoke-exposed mice were significantly increased [118]. Increased BAL inflammatory cytokine secretion such as keratinocyte chemoattractant (KC), TNF- $\alpha$ [84], macrophage inflammatory proteins (MIP-2 and MIP-1 $\alpha$ ) and MCP-1 were also observed in animal models of CS-induced COPD [22]. Increased levels of ILs (IL-12 and IL-4) and chemokines (CXCL-10 and CCL-22) in BAL of LPS-exposed mice were also reported [79, 80]. 
Table 3 Inflammatory cells and mediators in the blood and lung lavage of different animal models of COPD

\begin{tabular}{|c|c|c|c|c|}
\hline Sample & Parameters & Animals & Methods & References \\
\hline \multirow[t]{5}{*}{ Blood } & WBC & Guinea pig & - Total WBC & {$[51]$} \\
\hline & & & - Total WBC and Eosinophils in blood & {$[50,53]$} \\
\hline & Mediators \& Cytokines & Rat & - TNF-a, IL-8, IL-10 & {$[2]$} \\
\hline & & Guinea pig & $-\operatorname{IL}-8$ & {$[50,52,53]$} \\
\hline & & & $-M D A$ & {$[50,51,53]$} \\
\hline \multirow[t]{12}{*}{ Lavage } & WBC & Mice & - - Total cell and Macrophages, lymphocytes, neutrophils & {$[29,30,32,34,77,136,137]$} \\
\hline & & & - Macrophages and neutrophils (Cells) & {$[33,64]$} \\
\hline & & Rat & - Total leukocytes, macrophage, neutrophils and lymphocyte & {$[39,41,42]$} \\
\hline & & & -dfd - Total cell and neutrophils in lung lavage & {$[81]$} \\
\hline & & Guinea pig & - Total WBC, eosinophils and neutrophils in lung lavage & {$[52]$} \\
\hline & Mediators \& Cytokines & Mice & - IL-8, TNF- $a$, IFN- $\gamma$ & [118] \\
\hline & & & $\begin{array}{l}\text { - KC, TNF- a, MIP-2, MIP-1a, MCP-1 } \\
\text { - TNF- a } \\
\text { - IL-12, IL-4, CXCL-10, CCL-22 }\end{array}$ & $\begin{array}{l}{[22]} \\
{[32]} \\
{[79,80]}\end{array}$ \\
\hline & & Rat & - TNF-a, IL-8, IL-10 & {$[2]$} \\
\hline & & & - Total protein & {$[81]$} \\
\hline & & & - Total protein, TNF-a & [121] \\
\hline & & & - Total protein, IL-6, IL-1 $\beta$, TNF- a & {$[98]$} \\
\hline & & Guinea pig & $-\mid \mathrm{L}-8$ & {$[52]$} \\
\hline
\end{tabular}

WBC white blood cell, TNF- $a$ tumor necrosis factor alpha, ILs (IL-1 $\beta, I L-4, I L-6, I L-8, I L-10, I L-12)$ interleukin-1 $\beta, 4,6,8,10,12, M D A$ malondialdehyde, IFN- $\gamma$ interferon gamma, KC keratinocyte chemoattractant, MIPs (MIP-2 and MIP-1a) macrophage inflammatory proteins, MCP-1 monocyte chemoattractant protein-1

\section{Rats}

Increased levels of TNF- $\alpha$, IL-8, and IL-10 were seen in both serum and BAL of CS-exposed rats [2]. The levels of total protein in the BAL fluid were also significantly enhanced in rat models of COPD induced by a combination of CS and LPS [81]. In another study, the levels of TNF- $\alpha$ and total protein in the BAL fluid were elevated in rats with CS-induced COPD [121]. Similarly, total protein content and also some proinflammatory cytokines such as IL- 6 , IL- $1 \beta$, and TNF- $\alpha$ in BAL were increased in rats after elastase treatment [98].

\section{Guinea pigs}

Increased serum levels of IL-8 and malondialdehyde (MDA) in guinea pigs model of COPD induced by CS, were reported $[50,51,53]$. In addition, Feizpour et al. indicated that the level of IL- 8 in serum and BAL of guinea pig models of CS-induced COPD, were increased [52]. Inflammatory mediators and cytokines changes in the blood and lung lavage in different animal models of COPD were presented in Table 3 .

\section{Conclusion}

There is an enormous diversity of methods by which a study on COPD in animals can be done. Thus, there is a need for a standard protocol, which defines parameters to be evaluated and procedures (e.g. exposure procedure) to be followed. For development of an animal model representative of COPD, methods for induction of COPD, parameters for assessment and characteristics of human COPD should be assessed. In the present review, information regarding induction of experimental models of COPD in different animals, various methods used for this purpose, and different parameters that should be measured, was provided. This essential information is valuable for designing appropriate studies in future investigations on COPD.

\begin{abstract}
Abbreviations
AHR: Airway hyperresponsiveness; BAL: Bronchoalveolar lavage; Cig: Cigarette; COPD: Chronic obstructive pulmonary; CRC: Concentration response curve; CS: Cigarette-smoke; EC50: Effective concentration causing $50 \%$ of maximum response; IFN- $\gamma$ : Interferon gamma; ILs: Interleukins; IN: Intranasal; IT: Intra tracheal; KC: Keratinocyte chemoattractant; LPS: Lipopolysaccharide; LTB4: Leukotriene B4; Mch: Methacholine; MCP-1: Monocyte chemotactic protein 1; MDA: Malondialdehyde; MIPs: Macrophage inflammatory proteins; PPE: Porcine pancreatic elastase; ROS: Reactive oxygen species; TC: Tracheal chain; TNF-a: Tumor necrosis factor alpha; TPM: Total particulate matter; TR: Tracheal responsiveness; TSP: Total suspended particles; VEGF: Vascular endothelial growth factor; WBC: White blood cell; WBPle: Whole-body plethysmograph
\end{abstract}

\section{Acknowledgements}

Not applicable (It is a review article).

Funding

There was not financial support in this article. 


\section{Authors' contributions}

VG, MRK, MK and MHB all participated in the preparing of the draft of the manuscript. All authors read and approved the final manuscript.

\section{Competing interests}

The authors declare that they have no competing interests.

\section{Consent for publication}

Not applicable (It is a review article).

\section{Ethics approval and consent to participate}

Not applicable (It is a review article).

The name of the ethics committee that approved the study and the committee's reference number

Not applicable (It is a review article).

\section{Publisher's Note}

Springer Nature remains neutral with regard to jurisdictional claims in published maps and institutional affiliations.

\section{Author details}

'Pharmaceutical Research Centre and Department of Physiology, School of Medicine, Mashhad University of Medical Sciences, Mashhad, Iran.

${ }^{2}$ Neurogenic Inflammation Research Centre and Department of Physiology, School of Medicine, Mashhad University of Medical Sciences, Mashhad 9177948564, Iran.

Received: 19 November 2016 Accepted: 19 April 2017

Published online: 02 May 2017

\section{References}

1. Beckett EL, Stevens RL, Jarnicki AG, Kim RY, Hanish I, Hansbro NG, et al. A new short-term mouse model of chronic obstructive pulmonary disease identifies a role for mast cell tryptase in pathogenesis. J Allergy Clin Immunol. 2013;131(3):752-62. e757.

2. Li Y, Li S-Y, Li J-S, Deng L, Tian Y-G, Jiang S-L, et al. A rat model for stable chronic obstructive pulmonary disease induced by cigarette smoke inhalation and repetitive bacterial infection. Biol Pharm Bull. 2012;35(10):1752-60.

3. Martorana PA, Cavarra E, Lucattelli M, Lungarella G. Models for COPD involving cigarette smoke. Drug Discov Today Dis Models. 2006;3(3):225-30.

4. Brusselle G, Bracke K, Maes T, D'hulst A, Moerloose K, Joos G, et al. Murine models of COPD. Pulm Pharmacol Ther. 2006;19(3):155-65.

5. Canning BJ, Wright JL. Animal models of asthma and chronic obstructive pulmonary disease. Pulm Pharmacol Ther. 2008;21(5):695.

6. Wright JL, Churg A. Animal models of COPD: barriers, successes, and challenges. Pulm Pharmacol Ther. 2008;21(5):696-8.

7. Eltom S, Stevenson C, Birrell MA. Cigarette smoke exposure as a model of inflammation associated with COPD. Curr Protoc Pharmacol. 2013:14.24. 1114.24. 18.

8. Vlahos R, Bozinovski S, Gualano R, Ernst M, Anderson G. Modelling COPD in mice. Pulm Pharmacol Ther. 2006;19(1):12-7.

9. Pera T. Inflammation and remodelling in experimental models of COPD. 2011.

10. Groneberg DA, Chung KF. Models of chronic obstructive pulmonary disease. Respir Res. 2004;5(1):18.

11. Mortaz E, Adcock IA. Limitation of COPD Studies in Animal Modeling. Tanaffos. 2012;11(3):7.

12. Bonfield TL. In vivo models of lung disease. in: Lung diseases - selected state of the art Reviews, InTech. 2012:407-28.

13. Leberl M, Kratzer A, Taraseviciene-Stewart L. Tobacco smoke induced COPD/ emphysema in the animal model-are we all on the same page? Front Physiol. 2013;4.

14. O'byrne P, Postma D. The many faces of airway inflammation: asthma and chronic obstructive pulmonary disease. Am J Respir Crit Care Med. 1999; 159(supplement_2):S1-S63.

15. Churg A, Tai H, Coulthard T, Wang R, Wright JL. Cigarette smoke drives small airway remodeling by induction of growth factors in the airway wall. Am J Respir Crit Care Med. 2006;174(12):1327-34.
16. Wright IL, Cosio M, Churg A. Animal models of chronic obstructive pulmonary disease. Am J Physiol Lung Cell Mol Physiol. 2008;295(1):L1-L15.

17. Wright J, Postma D, Kerstjens H, Timens W, Whittaker P, Churg A. Airway remodeling in the smoke exposed guinea pig model. Inhal Toxicol. 2007: 19(11):915-23.

18. Bracke K, D'hulst A, Maes T, Demedts I, Moerloose K, Kuziel W, et al. Cigarette smoke-induced pulmonary inflammation, but not airway remodelling, is attenuated in chemokine receptor 5-deficient mice. Clin Exp Allergy. 2007;37(10):1467-79.

19. Churg A, Cosio M, Wright JL. Mechanisms of cigarette smoke-induced COPD: insights from animal models. Am J Physiol Lung Cell Mol Physiol. 2008;294(4):L612-31.

20. Wright JL, Churg A. Animal models of cigarette smoke-induced COPD. CHEST Journal. 2002;122(6_suppl):301S-6S.

21. Wright IL, Churg A. Animal models of cigarette smoke-induced chronic obstructive pulmonary disease. 2010.

22. John G, Kohse K, Orasche J, Reda A, Schnelle-Kreis J, Zimmermann R, et al. The composition of cigarette smoke determines inflammatory cell recruitment to the lung in COPD mouse models. Clin Sci. 2014;126(3):207-21.

23. Mallia P, Johnston SL. Mechanisms and experimental models of chronic obstructive pulmonary disease exacerbations. Proc Am Thorac Soc. 2005; 2(4):361-6.

24. March TH, Barr EB, Finch GL, Hahn FF, Hobbs CH, Ménache MG, et al. Cigarette smoke exposure produces more evidence of emphysema in B6C3F1 mice than in F344 rats. Toxicol Sci. 1999;51(2):289-99.

25. Adamson J, Haswell LE, Phillips G, Gaça MD. In vitro models of chronic obstructive pulmonary disease (COPD). In Bronchitis, ed. I Martin-Loeches. InTech. 2011:41-66.

26. Hardaker L, Bahra P, de Billy BC, Freeman M, Kupfer N, Wyss D, et al. The ion channel transient receptor potential melastatin-2 does not play a role in inflammatory mouse models of chronic obstructive pulmonary diseases. Respir Res. 2012:13:30.

27. Motz GT, Eppert BL, Wesselkamper SC, Flury JL, Borchers MT. Chronic cigarette smoke exposure generates pathogenic T cells capable of driving COPD-like disease in Rag2-/- mice. Am J Respir Crit Care Med. 2010; 181(11):1223-33.

28. Motz GT, Eppert BL, Wortham BW, Amos-Kroohs RM, Flury JL, Wesselkamper SC, et al. Chronic cigarette smoke exposure primes NK cell activation in a mouse model of chronic obstructive pulmonary disease. J Immunol. 2010; 184(8):4460-9.

29. Cremona TP, Tschanz SA, von Garnier C, Benarafa C. SerpinB1 deficiency is not associated with increased susceptibility to pulmonary emphysema in mice. Am J Physiol Lung Cell Mol Physiol. 2013;305(12):L981-9.

30. Jobse BN, Rhem RG, Wang IQ, Counter WB, Stämpfli MR, Labiris NR. Detection of lung dysfunction using ventilation and perfusion SPECT in a mouse model of chronic cigarette smoke exposure. J Nucl Med. 2013; 54(4):616-23.

31. Barrett EG, Wilder JA, March TH, Espindola T, Bice DE. Cigarette smoke-induced airway hyperresponsiveness is not dependent on elevated immunoglobulin and eosinophilic inflammation in a mouse model of allergic airway disease. Am J Respir Crit Care Med. 2002;165(10):1410-8.

32. Hansbro P, Beckett E, Stevens R, Jarnicki A, Wark P, Foster P. A short-term model of COPD identifies a role for mast cell tryptase. Eur Respir J. 2013;42 Suppl 57:664.

33. Zhou S, Wright JL, Liu J, Sin DD, Churg A. Aging does not Enhance Experimental Cigarette Smoke-Induced COPD in the Mouse. PLoS One. 2013;8(8), e71410

34. Tanabe N, Hoshino Y, Marumo S, Kiyokawa H, Sato S, Kinose D, et al. Thioredoxin-1 protects against neutrophilic inflammation and emphysema progression in a mouse model of chronic obstructive pulmonary disease exacerbation. PLoS One. 2013;8(11), e79016.

35. Stevenson CS, Docx C, Webster R, Battram C, Hynx D, Giddings J, et al. Comprehensive gene expression profiling of rat lung reveals distinct acute and chronic responses to cigarette smoke inhalation. Am J Physiol Lung Cell Mol Physiol. 2007;293(5):L1183-93.

36. Kratzer A, Salys J, Nold-Petry C, Cool C, Zamora M, Bowler R, et al. Role of IL-18 in Second-Hand Smoke-Induced Emphysema. Am J Respir Cell Mol Biol. 2013;48(6):725-32

37. Kozma RH, Alves EM, Barbosa-de-Oliveira VA, Lopes FDTQ, Guardia RC, Buzo $\mathrm{HV}$, et al. A new experimental model of cigarette smoke-induced emphysema in Wistar rats. J Bras Pneumol. 2014;40(1):46-4. 
38. Wang $Y$, Jiang $X$, Zhang $L$, Wang $L$, Li Z, Sun W. Simvastatin mitigates functional and structural impairment of lung and right ventricle in a rat model of cigarette smoke-induced COPD. Int J Clin Exp Pathol. 2014; 7(12):8553-62.

39. Davis BB, Shen Y-H, Tancredi DJ, Flores V, Davis RP, Pinkerton KE. Leukocytes are recruited through the bronchial circulation to the lung in a spontaneously hypertensive rat model of COPD. PLoS One. 2012; 7(3), e33304.

40. Ramírez-Romero R, Nevárez-Garza AM, Rodríguez-Tovar LE, Wong-González A, Ledezma-Torres RA, Hernández-Vidal G. Histopathological Analogies in Chronic Pulmonary Lesions between Cattle and Humans: Basis for an Alternative Animal Model. Sci Word J. 2012;2012.

41. Smith KR, Pinkerton KE, Watanabe T, Pedersen TL, Ma SJ, Hammock BD. Attenuation of tobacco smoke-induced lung inflammation by treatment with a soluble epoxide hydrolase inhibitor. Proc Natl Acad Sci USA. 2005: 102(6):2186-91.

42. Zheng H, Liu Y, Huang T, Fang Z, Li G, He S. Development and characterization of a rat model of chronic obstructive pulmonary disease (COPD) induced by sidestream cigarette smoke. Toxicol Lett. 2009;189(3):225-34.

43. Canning BJ. Modeling asthma and COPD in animals: a pointless exercise? Curr Opin Pharmacol. 2003;3(3):244-50.

44. Wright JL, Churg A. Cigarette Smoke Causes Physiologic and Morphologic Changes of Emphysema in the Guinea Pig1-3. Am Rev Respir Dis. 1990;142:1422-8.

45. Bourbon JR, Boucherat O, Boczkowski J, Crestani B, Delacourt C Bronchopulmonary dysplasia and emphysema: in search of common therapeutic targets. Trends Mol Med. 2009;15(4):169-79.

46. Canning BJ, Chou Y. Using guinea pigs in studies relevant to asthma and COPD. Pulm Pharmacol Ther. 2008;21(5):702-20.

47. Ressmeyer A, Larsson A, Vollmer E, Dahlén S-E, Uhlig S, Martin C. Characterisation of guinea pig precision-cut lung slices: comparison with human tissues. Eur Respir J. 2006;28(3):603-11.

48. Muccitelli R, Tucker S, Hay D, Torphy $T$, Wasserman M. Is the guinea pig trachea a good in vitro model of human large and central airways? Comparison on leukotriene-, methacholine-, histamine-and antigen-induced contractions. J Pharmacol Exp Ther. 1987;243(2):467-73.

49. Dalen $\mathrm{H}$. An ultrastructural study of the tracheal epithelium of the guineapig with special reference to the ciliary structure. J Anat. 1983;136(Pt 1):47.

50. Boskabady $\mathrm{MH}$, Gholami ML. Effect of the Zataria multiflora on systemic inflammation of experimental animals model of COPD. Biomed Res Int. $2014,2014$.

51. Ghorbani A, Feizpour A, Hashemzahi M, Gholami L, Hosseini M, Soukhtanloo $M$, et al. The effect of adipose derived stromal cells on oxidative stress level, lung emphysema and white blood cells of guinea pigs model of chronic obstructive pulmonary disease. Daru. 2014;22(1):22-6.

52. Feizpour A, Boskabady MH, Ghorbani A. Adipose-Derived Stromal Cell Therapy Affects Lung Inflammation and Tracheal Responsiveness in Guinea Pig Model of COPD. 2014

53. Mahtaj LG, Feizpour A, Kianmehr M, Soukhtanloo M, Boskabady MH. The effect of carvacrol on systemic inflammation in guinea pigs model of COPD induced by cigarette smoke exposure. Pharmacol Rep. 2015;67(1):140-5.

54. Boskabady MH, Kiani S, Khoei AR, Aslani MR. Tracheal Responsiveness to Histamine and Histamine (H1) Receptor Blockade by Chlorpheniramine in an Animal Model of COPD. Int J Pharmacol. 2005:1(4):350-6.

55. Boskabady MH, Kiani S, Aslani MR. Tracheal responsiveness to both isoprenaline and beta2-adrenoreceptor blockade by propranolol in cigarette smoke exposed and sensitized guinea pigs. Respirology. 2006;11(5):572-8.

56. Boskabady MH, Jandaghi PP. Tracheal responsivness to methacholine and muscarinic receptor blockade by atropine in animal model of COPD. Pharmacologyonline. 2006;2:307-23.

57. Boskabady M, Kiani S. The effect of exposure of guinea pig to cigarette smoke and their sensitization in tracheal responsiveness to histamine and

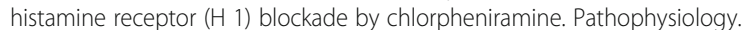
2007;14(2):97-4

58. Keyhanmanesh $R$, Nazemiyeh $H$, Mazouchian $H$, Asl MMB, Shoar MK, Alipour $M R$, et al. Nigella sativa pretreatment in guinea pigs exposed to cigarette smoke modulates in vitro tracheal responsiveness. Iran Red Crescent Med J. 2014;16:e10421.

59. Chapman RW. Canine models of asthma and COPD. Pulm Pharmacol Ther 2008;21(5):731-42
60. Auerbach O, Hammond EC, Kirman D, Garfinkel L. Emphysema produced in dogs by cigarette smoking. Jama. 1967;199(4):241-6.

61. Park SS, Kikkawa Y, Goldring IP, Daly MM, Zelefsky M, Shim C, et al. An Animal Model of Cigarette Smoking in Beagle Dogs: Correlative Evaluation of Effects on Pulmonary Function, Defense, and Morphology 1, 2. Am Rev Respir Dis. 1977;115(6):971-9.

62. Frasca J, Auerbach O, Carter H, Parks V. Morphologic alterations induced by short-term cigarette smoking. Am J Pathol. 1983;111(1):11.

63. Plopper CG, Hyde DM. The non-human primate as a model for studying COPD and asthma. Pulm Pharmacol Ther. 2008;21(5):755-66.

64. Zhu L, Di PY, Wu R, Pinkerton KE, Chen Y. Repression of CC16 by Cigarette Smoke (CS) Exposure. PLoS One. 2015;10(1), e0116159.

65. Wang $L$, Joad JP, Zhong C, Pinkerton KE. Effects of environmental tobacco smoke exposure on pulmonary immune response in infant monkeys. J Allergy Clin Immunol. 2008;122(2):400-6. e405.

66. Fehrenbach $\mathrm{H}$. Animal models of pulmonary emphysema: a stereologist's perspective. Eur Respir Rev. 2006;15(101):136-47.

67. Hasday JD, Bascom R, Costa JJ, Fitzgerald T, Dubin W. Bacterial endotoxin is an active component of cigarette smoke. CHEST Journal. 1999;115(3):829-35.

68. Rylander R. Endotoxin and occupational airway disease. Curr Opin Allergy Clin Immunol. 2006:6(1):62-6.

69. Pera T, Zuidhof A, Valadas J, Smit M, Schoemaker RG, Gosens R, et al. Tiotropium inhibits pulmonary inflammation and remodelling in a guinea pig model of COPD. Eur Respir J. 2011;38(4):789-96.

70. Patel I, Seemungal T, Wilks M, Lloyd-Owen S, Donaldson G, Wedzicha J. Relationship between bacterial colonisation and the frequency, character, and severity of COPD exacerbations. Thorax. 2002;57(9):759-64.

71. Spond J, Case N, Chapman R, Crawley Y, Egan R, Fine J, et al. Inhibition of experimental acute pulmonary inflammation by pirfenidone. Pulm Pharmacol Ther. 2003;16(4):207-14.

72. Toward TJ, Broadley KJ. Airway reactivity, inflammatory cell influx and nitric oxide in guinea-pig airways after lipopolysaccharide inhalation. Br J Pharmacol. 2000;131(2):271-81.

73. Vernooy $\mathrm{JH}$, Dentener MA, Van Suylen RJ, Buurman WA, Wouters EF. Intratracheal instillation of lipopolysaccharide in mice induces apoptosis in bronchial epithelial cells: no role for tumor necrosis factor-a and infiltrating neutrophils. Am J Respir Cell Mol Biol. 2001;24(5):569-76.

74. Brass DM, Hollingsworth JW, Cinque M, Li Z, Potts E, Toloza E, et al. Chronic LPS inhalation causes emphysema-like changes in mouse lung that are associated with apoptosis. Am J Respir Cell Mol Biol. 2008: 39(5):584-90

75. Toward TJ, Broadley KJ. Goblet cell hyperplasia, airway function, and leukocyte infiltration after chronic lipopolysaccharide exposure in conscious Guinea pigs: effects of rolipram and dexamethasone. J Pharmacol Exp Ther. 2002;302(2):814-21.

76. Vernooy JH, Dentener MA, Van Suylen RJ, Buurman WA, Wouters EF. Longterm intratracheal lipopolysaccharide exposure in mice results in chronic lung inflammation and persistent pathology. Am J Respir Cell Mol Biol. 2002:26(1):152-9.

77. Sohn S-H, Jang H, Kim Y, Jang YP, Cho S-H, Jung H, et al. The effects of Gamijinhae-tang on elastase/lipopolysaccharide-induced lung inflammation in an animal model of acute lung injury. BMC Complement Altern Med. 2013;13(1):176.

78. Sajjan U, Ganesan S, Comstock AT, Shim J, Wang Q, Nagarkar DR, et al. Elastase-and LPS-exposed mice display altered responses to rhinovirus infection. Am J Physiol Lung Cell Mol Physiol. 2009;297(5):L931-44.

79. Al Faraj A, Shaik AS, Afzal S, Al Sayed B, Halwani R. MR imaging and targeting of a specific alveolar macrophage subpopulation in LPS-induced COPD animal model using antibody-conjugated magnetic nanoparticles. Int J Nanomedicine. 2014;9:1491.

80. Al Faraj A, Shaik AS, Pureza MA, Alnafea M, Halwani R. Preferential macrophage recruitment and polarization in LPS-induced animal model for COPD: noninvasive tracking using MRI. PLoS One. 2014;9(3), e90829.

81. Hardaker E, Freeman M, Dale N, Bahra P, Raza F, Banner K, et al. Exposing rodents to a combination of tobacco smoke and lipopolysaccharide results in an exaggerated inflammatory response in the lung. Br J Pharmacol. 2010; 160(8):1985-96.

82. Baarsma HA, Bos S, Meurs H, Visser KH, Smit M, Schols A, et al. Pharmacological inhibition of GSK-3 in a guinea pig model of LPS-induced pulmonary inflammation: I. Effects on lung remodeling and pathology. Respir Res. 2013;14(1):113. 
83. Janoff A. Elastases and Emphysema: Current Assessment of the ProteaseAntiprotease Hypothesis 1-3. Am Rev Respir Dis. 1985;132(2):417-33.

84. Antunes MA, Rocco PR. Elastase-induced pulmonary emphysema: insights from experimental models. An Acad Bras Cienc. 2011;83(4):1385-96.

85. Snider GL, Lucey EC, Stone PJ. Animal Models of Emphysema 1-3. Am Rev Respir Dis. 1986;133(1):149-69.

86. Emphysema GL. The first two centuries and beyond. A historial overview, with suggestions for future research: Part I. Am Rev Respir Dis. 1992;146: 1334-44.

87. Petrache I, Fijalkowska I, Medler TR, Skirball J, Cruz P, Zhen L, et al. a-1 Antitrypsin inhibits caspase-3 activity, preventing lung endothelial cell apoptosis. Am J Pathol. 2006;169(4):1155-66.

88. Karaaslan Ç, Hirakawa H, Yasumatsu R, Chang L-YL, Pierce RA, Crapo JD, et al. Elastase Inhibitory Activity of Airway \&agr; 1-Antitrypsin Is Protected by Treatment With a Catalytic Antioxidant in a Baboon Model of Severe Bronchopulmonary Dysplasia. Pediatr Res. 2011;70(4):363-7.

89. Chen JC, Brenner M, Kafie FE, Yoong B, Budd M, Gassel A, et al. An animal model for lung volume reduction therapy of pulmonary emphysema. J Invest Surg. 1998;11(2):129-37.

90. Ito S, Ingenito EP, Brewer KK, Black LD, Parameswaran H, Lutchen KR, et al. Mechanics, nonlinearity, and failure strength of lung tissue in a mouse model of emphysema: possible role of collagen remodeling. J Appl Physiol. 2005;98(2):503-11.

91. Rohrer J, Wuertz BR, Ondrey F. Cigarette smoke condensate induces nuclear factor kappa-b activity and proangiogenic growth factors in aerodigestive cells. Laryngoscope. 2010;120(8):1609-13.

92. Rose JE, Behm FM, Murugesan T, McClernon FJ. Silver acetate interactions with nicotine and non-nicotine smoke components. Exp Clin Psychopharmacol. 2010;18(6):462.

93. Lieberman J. Elastase, collagenase, emphysema, and alpha1-antitrypsin deficiency. Chest. 1976;70:62-7.

94. Ishizawa K, Kubo H, Yamada M, Kobayashi S, Numasaki M, Ueda S, et al. Bone marrow-derived cells contribute to lung regeneration after elastaseinduced pulmonary emphysema. FEBS Lett. 2004;556(1):249-52.

95. Vidal D, Fortunato G, Klein W, Cortizo L, Vasconcelos J, Ribeiro-Dos-Santos R, et al. Alterations in pulmonary structure by elastase administration in a model of emphysema in mice is associated with functional disturbances. Rev Port Pnemol (English Edition). 2012;18(3):128-36.

96. Borzone G, Ramírez B, Reyes T, Moreno R, Lisboa C, González S. Experimental pulmonary emphysema in rats. Inflammatory phenomena and progression of lung damage. Rev Med Chil. 1998;126(10):1153-60.

97. Borzone G, Liberona L, Olmos P, Sáez C, Meneses M, Reyes T, et al. Rat and hamster species differences in susceptibility to elastase-induced pulmonary emphysema relate to differences in elastase inhibitory capacity. Am J Physiol Regul Integr Comp Physiol. 2007;293(3):R1342-9.

98. Vecchiola A, de la Llera JF, Ramírez R, Olmos P, Herrera Cl, Borzone G. Differences in acute lung response to elastase instillation in two rodent species may determine differences in severity of emphysema development. Am J Physiol Regul Integr Comp Physiol. 2011;301(1):R148-58.

99. Marwick JA, Stevenson CS, Giddings J, MacNee W, Butler K, Rahman I, et al. Cigarette smoke disrupts VEGF165-VEGFR-2 receptor signaling complex in rat lungs and patients with COPD: morphological impact of VEGFR-2 inhibition. Am J Physiol Lung Cell Mol Physiol. 2006;290(5):L897-8.

100. Kasahara Y, Tuder RM, Taraseviciene-Stewart L, Le Cras TD, Abman S, Hirth PK, et al. Inhibition of VEGF receptors causes lung cell apoptosis and emphysema. J Clin Invest. 2000;106(11):1311.

101. Taraseviciene-Stewart L, Scerbavicius R, Choe K-H, Moore M, Sullivan A, Nicolls MR, et al. An animal model of autoimmune emphysema. Am J Respir Crit Care Med. 2005;171(7):734-42.

102. Shapiro SD. Animal models for chronic obstructive pulmonary disease: age of klotho and marlboro mice. Am J Respir Cell Mol Biol. 2000;22(1):4-7.

103. Shapiro SD. Animal models for COPD. CHEST Journal. 2000;117 (5_suppl_1):223S-7S.

104. Mahadeva R, Shapiro S. Chronic obstructive pulmonary disease. 3 : Experimental animal models of pulmonary emphysema. Thorax. 2002;57(10):908-14.

105. Hautamaki RD, Kobayashi DK, Senior RM, Shapiro SD. Requirement for macrophage elastase for cigarette smoke-induced emphysema in mice. Science. 1997;277(5334):2002-4.

106. Shapiro SD. The use of transgenic mice for modeling airways disease. Pulm Pharmacol Ther. 2008;21(5):699-1.
107. Shapiro SD, Goldstein NM, Houghton AM, Kobayashi DK, Kelley D, Belaaouaj A. Neutrophil elastase contributes to cigarette smoke-induced emphysema in mice. Am J Pathol. 2003;163(6):2329-35.

108. Zheng T, Zhu Z, Wang Z, Homer RJ, Ma B, Riese Jr RJ, et al. Inducible targeting of IL-13 to the adult lung causes matrix metalloproteinase-and cathepsin-dependent emphysema. J Clin Invest. 2000;106(9):1081.

109. Wang Z, Zheng T, Zhu Z, Homer RJ, Riese RJ, Chapman HA, et al. Interferon $\gamma$ induction of pulmonary emphysema in the adult murine lung. J Exp Med. 2000;192(11):1587-600.

110. Cosio M, Ghezzo H, Hogg J, Corbin R, Loveland M, Dosman J, et al. The relations between structural changes in small airways and pulmonaryfunction tests. N Engl J Med. 1978;298(23):1277-81.

111. Penman RW, O'Neill RP, Begley L. The Progress of Chronic Airway Obstruction in Relation to Measurements of Airway Resistance and Lung Elastic Recoil 1, 2. Am Rev Respir Dis. 1970;101(4):536-44.

112. Colebatch H, Finucane K, Smith M. Pulmonary conductance and elastic recoil relationships in asthma and emphysema. J Appl Physiol. 1973; 34(2):143-53.

113. Pauwels RA, Buist AS, Calverley PM, Jenkins CR, Hurd $S$, on behalf of the GOLD Scientific Committee: Global strategy for the diagnosis, management, and prevention of chronic obstructive pulmonary disease. NHLBI/WHO Global Initiative for Chronic Obstructive Lung Disease (GOLD) workshop summary. Am J Respir Crit Care Med. 2001;163(5):1256-76

114. Eisner MD, Anthonisen N, Coultas D, Kuenzli N, Perez-Padilla R, Postma D, et al. An official American Thoracic Society public policy statement: Novel risk factors and the global burden of chronic obstructive pulmonary disease. Am J Respir Crit Care Med. 2010;182(5):693-18.

115. Murray CJ, Lopez AD. Alternative projections of mortality and disability by cause 1990-2020: Global Burden of Disease Study. Lancet. 1997; 349(9064):1498-4.

116. Barnes PJ. Immunology of asthma and chronic obstructive pulmonary disease. Nat Rev Immunol. 2008:8(3):183-92.

117. Hogg JC, Timens W. The pathology of chronic obstructive pulmonary disease. Annu Rev Pathol-Mech. 2009:4:435-59.

118. Duan M-C, Tang H-J, Zhong X-N, Huang Y. Persistence of Th17/Tc17 cell expression upon smoking cessation in mice with cigarette smoke-induced emphysema. Clin Dev Immunol. 2013;2013.

119. Braber S, Henricks PA, Nijkamp FP, Kraneveld AD, Folkerts G. Inflammatory changes in the airways of mice caused by cigarette smoke exposure are only partially reversed after smoking cessation. Respir Res. 2010;11(1):99.

120. Cavarra E, Bartalesi B, Lucattelli M, Fineschi S, Lunghi B, Gambelli F, et al. Effects of cigarette smoke in mice with different levels of a1-proteinase inhibitor and sensitivity to oxidants. Am J Respir Crit Care Med. 2001;164(5):886-90.

121. Rafiq M, Viswanatha GL, Suryakanth DA, Azeemuddin M, Jagadeesh M, Dhanush K, et al. Poly-Ingredient Formulation Bresol ${ }^{\oplus}$ Ameliorates Experimental Chronic Obstructive Pulmonary Disease (COPD) in Rats. Sci Pharm. 2013;81(3):833.

122. James AL, Dirks P, Ohtaka H, Schellenberg R, Hogg JC. Airway responsiveness to intravenous and inhaled acetylcholine in the guinea pig after cigarette smoke exposure. Am J Respir Crit Care Med. 1987;136(5): 1158-62.

123. Dusser D, Djokic T, Borson D, Nadel J. Cigarette smoke induces bronchoconstrictor hyperresponsiveness to substance $P$ and inactivates airway neutral endopeptidase in the guinea pig. Possible role of free radicals. J Clin Invest. 1989;84(3):900.

124. Kuo H-P, Lu L-C. Sensory neuropeptides modulate cigarette smoke-induced decrease in neutral endopeptidase activity in guinea pig airways. Life Sci. 1995;57(23):2187-96

125. Lee L-Y, Lou Y-P, Hong J-L, Lundberg JM. Cigarette smoke-induced bronchoconstriction and release of tachykinins in guinea pig lungs. Respir physiolo. 1995;99(1):173-81.

126. Hulbert W, McLean T, Hogg J. The Effect of Acute Airway Inflammation on Bronchial Reactivity in Guinea Pigs 1-3. Am Rev Respir Dis. 1985;132(1):7-11.

127. Hamelmann E, Schwarze J, Takeda K, Oshiba A, Larsen G, Irvin C, et al. Noninvasive measurement of airway responsiveness in allergic mice using barometric plethysmography. Am J Respir Crit Care Med. 1997; 156(3):766-75.

128. Boskabady MH, Teymoory S. The influence of epithelium on the responsiveness of quinea-pig trachea to ß-adrenergic agonist and antagonist. Med Sci Monit. 2003;9(9):BR336-42. 
129. Neamati A, Boskabady MH, Afshari JT, Hazrati SM, Rohani AH. The effect of natural adjuvants on tracheal responsiveness and cell count in lung lavage of sensitized guinea pigs. Respirology. 2009;14(6):877-84.

130. Saetta M, Di Stefano A, Turato G, Facchini FM, Corbino L, Mapp CE, et al. CD8+ T-lymphocytes in peripheral airways of smokers with chronic obstructive pulmonary disease. Am J Respir Crit Care Med. 1998;157(3):822-6.

131. Saetta M, Di Stefano A, Maestrelli P, Ferraresso A, Drigo R, Potena A, et al. Activated T-lymphocytes and macrophages in bronchial mucosa of subjects with chronic bronchitis. Am Rev Respir Dis. 1993;147(2):301-6.

132. Saetta M, Baraldo S, Corbino L, Turato G, Braccioni F, Rea F, et al. CD8+ ve cells in the lungs of smokers with chronic obstructive pulmonary disease. Am J Respir Crit Care Med. 1999;160(2):711-7.

133. Vlahos R. Preclinical animal models of COPD. J Inflam. 2013;10 Suppl 1:25.

134. Cataldo D, Munaut C, Noël A, Frankenne F, Bartsch P, Foidart J-M, et al. MMP-2-and MMP-9-linked gelatinolytic activity in the sputum from patients with asthma and chronic obstructive pulmonary disease. Int Arch Allergy Immunol. 2000;123(3):259-67.

135. Vlahos R, Bozinovski S. Recent advances in pre-clinical mouse models of COPD. Clin Sci. 2014;126(4):253-65.

136. McGrath-Morrow SA, Lauer T, Collaco JM, Yee M, O'Reilly M, Mitzner W, et al. Neonatal Hyperoxia Contributes Additively to Cigarette Smoke??? Induced Chronic Obstructive Pulmonary Disease Changes in Adult Mice. Am J Respir Cell Mol Biol. 2011:45(3):610-6.

137. Maryanoff BE, de Garavilla L, Greco MN, Haertlein BJ, Wells Gl, AndradeGordon $\mathrm{P}$, et al. Dual inhibition of cathepsin $\mathrm{G}$ and chymase is effective in animal models of pulmonary inflammation. Am J Respir Crit Care Med. 2010;181(3):247-53.

138. Chung K. Cytokines in chronic obstructive pulmonary disease. Eur Respir J. 2001;18(34 suppl):50s-9s.

139. Keatings VM, Collins PD, Scott DM, Barnes PJ. Differences in interleukin-8 and tumor necrosis factor-alpha in induced sputum from patients with chronic obstructive pulmonary disease or asthma. Am J Respir Crit Care Med. 1996;153(2):530-4.

140. Barnes P, Shapiro S, Pauwels R. Chronic obstructive pulmonary disease: molecular and cellularmechanisms. Eur Respir J. 2003;22(4):672-88.

141. Wills-Karp M, Luyimbazi J, Xu X, Schofield B, Neben TY, Karp CL, et al. Interleukin-13: central mediator of allergic asthma. Science. 1998; 282(5397):2258-61.

142. Wright J, Zhou S, Churg A. Pulmonary hypertension and vascular oxidative damage in cigarette smoke exposed eNOS-/- mice and human smokers. Inhal Toxicol. 2012;24(11):732-40.

143. Wortham BW, Eppert BL, Motz GT, Flury JL, Orozco-Levi M, Hoebe K, et al. NKG2D mediates NK cell hyperresponsiveness and influenza-induced pathologies in a mouse model of chronic obstructive pulmonary disease. J Immunol. 2012;188(9):4468-75.

144. Bergren DR. Tobacco smoke exposure and bombesin-like peptides in guinea pigs. Peptides. 2002;23(5):919-26.

145. Simani AS, Inoue S, Hogg J. Penetration of the respiratory epithelium of guinea pigs following exposure to cigarette smoke. Laboratory investigation; a journal of technical methods and pathology. 1974;31(1):75.

146. Domínguez-Fandos D, Peinado VI, Puig-Pey R, Ferrer E, Musri MM, Ramírez J, et al. Pulmonary inflammatory reaction and structural changes induced by cigarette smoke exposure in the Guinea pig. COPD: Int J Chron Obstruct Pulmon Dis. 2012;9(5):473-84.

147. Wright JL, Zhou S, Preobrazhenska O, Marshall C, Sin DD, Laher I, et al. Statin reverses smoke-induced pulmonary hypertension and prevents emphysema but not airway remodeling. Am J Respir Crit Care Med. 2011; 183(1):50-8.

148. Churg A, Marshall CV, Sin DD, Bolton S, Zhou S, Thain K, et al. Late intervention with a myeloperoxidase inhibitor stops progression of experimental chronic obstructive pulmonary disease. Am J Respir Crit Care Med. 2012;185(1):34-3.

149. Stevens T, Ekholm K, Gränse M, Lindahl M, Kozma V, Jungar C, et al. AZD9668: pharmacological characterization of a novel oral inhibitor of neutrophil elastase. J Pharmacol Exp Ther. 2011;339(1):313-20.

150. Zwicker G, Filipy R, Park J, Loscutoff S, Ragan H, Stevens D. Clinical and pathological effects of cigarette smoke exposure in beagle dogs. Arch Pathol Lab Med. 1978;102(12):623-8.

151. King M, Wight A, Desanctis GT, El-Azab J, Phillips DM, Angus GE, et al. Mucus hypersecretion and viscoelasticity changes in cigarette-smoking dogs. Exp Lung Res. 1989;15(3):375-89.

\section{Submit your next manuscript to BioMed Central and we will help you at every step:}

- We accept pre-submission inquiries

- Our selector tool helps you to find the most relevant journal

- We provide round the clock customer support

- Convenient online submission

- Thorough peer review

- Inclusion in PubMed and all major indexing services

- Maximum visibility for your research

Submit your manuscript at www.biomedcentral.com/submit 